\title{
THE MUSLIM EXODUS AND THE EMERGENCE OF THE MODERN SERBIAN STATE IN THE FIRST HALF OF THE $19^{\text {TH }}$ CENTURY ${ }^{1}$
}

\section{Krzysztof Popek}

(1) http://orcid.org/0000-0001-5864-5264

Jagiellonian University in Kraków

\begin{abstract}
One of the main goals of Serbian Uprisings was to banish Muslims from the Serbian lands. After creation of the modern Serbian state, Serbia's status was still that of a half-autonomic province, and so its authorities tried to use agreements with the Sublime Porte to achieve this goal. Although Ottoman authorities repeatedly permitted the eviction of the Muslim population from the Principality, later on they did not implement the agreements, taking advantage of the weak Serbian position. In 1833, however, things changed: The Sublime Porte allowed the Serbian authorities to banish Muslims from their territory, including the six nahiyahs then incorporated into the Serbian state (Krajina, Crna Reka, Paraćin, Kruševac, Stari Vlah and Jadar with Rađevina).
\end{abstract}

Keywords: Serbia, $19^{\text {th }}$ century, Muslims in Serbia, Balkans, migrations.

In the $19^{\text {th }}$ century, the Balkans faced dramatic changes in terms of its political situation, but also in terms of tragedies of both individual families and whole social groups. The emergence of modern Balkan states and the collapse of Ottoman rule led to mass migrations. Muslims - not only the ruling class, but also small farmers and city dwellers - had to leave the lands where they had been living since their birth and where many generations of their ancestors had lived, only to make a place for Balkan Christians, who wanted to build a new socio-political reality. For Serbs, who started the first modern revolution in the Balkans in 1804, one of the most important goals was to banish Muslims from the reborn Serbian state.

Even though the process was crucial to the emergence of modern Serbia, historical research has disregarded this topic almost entirely: Serbian historians who study

${ }^{1}$ The research presented in this article was financed by the grant of the Polish National Science Center: The Balkan Migration Processes in the $19^{\text {th }}$ Century. Cases of Bulgaria and Serbia (2017/25/N/ HS3/00576).

\section{Address for correspondence: popek.kj@gmail.com}


migrations in the $19^{\text {th }}$ century have focused on the Serbian population, with Muslims being on the margin in these analyses. ${ }^{2}$ Those interested in the Islamic history in Balkans have preferred to analyze Muslim communities in Kosovo and Bosna. Western historians analyzing the Muslim exodus from the Balkan Peninsula during the collapse of Ottoman rule also have missed to discuss the situation in Serbia before the 1860 s. ${ }^{3}$ The topic thus creates an important gap to fill for historiography, especially if we realize that there are detailed studies on Muslim emigration from other Balkan countries in the $19^{\text {th }}$ century, especially Bulgaria. ${ }^{4}$ The Serbian Islamic community disappeared during the first fifty years after the creation of the Serbian state, and they have been forgotten ever since. Not only does this article analyze their fate, but it also serves to remind historians about all the turbulence and miseries both Muslims and Serbians experienced during those difficult times.

It is even difficult to describe the Muslims who lived in Serbia in the first half of the $19^{\text {th }}$ century. Most members of the Muslim population identified themselves through the prism of religion (as ummah) and membership in local communities (two exceptions being Albanians and Roma people, who constituted more complicate cases). At that time, national identity based on language and ethnic origin was not a widespread concept in the Balkan Peninsula, especially among Muslims. Most of the Muslims inhabiting the heart of the future Serbian state (the Belgrade Pashalik) were Slavic-speaking, Turkish-speaking, or Albanian-speaking, and many of them were assumed by Serbs to have Serbian origin. In 1860s, a Serbian writer Milan Đ. Milićević called Christian and Muslim citizens of Belgrade as "the brothers of the two faiths." ${ }^{\prime 5}$ Related historical sources often used the terms "Muslim," "Turk," "Arnaut," and "Arbanaš" (an Albanized and Islamized Serb) interchangeably. The

${ }^{2}$ For example: Р. Љуш ић, Кнежевина Србија (1830-1839), Београд 1986; Насељавање Србије. Насеља, порекло, становништва, обичаји, прир. Б. Чели ко в ић, Београд 2011.

${ }^{3}$ J. McCarthy, Death and Exile: The Ethnic Cleansing of the Ottoman Muslims 1821-1922, Princeton 1996; A. P o p ov i c, L'Islam balkanique, Les Musulmans du Sud-Est européen dans la période post-ottomane, Wiesbaden 1986; K. Popek, "Muslim Emigration from the Balkan Peninsula in the $19^{\text {th }}$ Century: A Historical Outline," Zeszyty Naukowe UJ. Prace Historyczne 2019, vol. 146, no. 3: Migrations, Migrants and Refugees in $19^{\text {th }}-21^{\text {st }}$ Centuries in the Interdisciplinary Approach. Selected Topics, eds. P. Sękowski, O. Forcade, R. Hudemann, pp. 517-533.

${ }^{4}$ For example: Ж. Назърска, Българската държсава и нейните малцинства 1878-1885 г., София 1999; Ö. Turan, The Turkish Minority in Bulgaria (1878-1908), Ankara 1998. In the case of Greece, the problem is similar: The literature focused on the 1923 resettlements, and even though some works have dealt with migrations after 1881, a lack of studies about the first half of the nineteenth-century exodus is evident. N. Immig, "The 'New' Muslim Minorities in Greece: Between Emigration and Political Participation, 1881-1886," Journal of Muslim Minority Affairs 2009, vol. 29, no. 4, pp. 511-522; S. Katsika s, "Millet Legacies in a National Environment: Political Elites and Muslim Communities in Greece (1830s-1923)" [in:] State-nationalisms in the Ottoman Empire, Greece and Turkey: Orthodox and Muslims, 1830-1945, eds. B. Fortna, S. Katsikas, D. Kamouzis, P. Konortas, AbingdonNew York 2013, pp. 47-84.

${ }^{5}$ M. Skrzeszew ska, "Poturica gori od Turčina or...? The Influence of Islam on 'Our Muslims' in Serbian Nationalistic Discourse (Review from the Second Half of the $19^{\text {th }}$ Century to the 1920s)" [in:] Turkish Yoke or Pax Ottomana: The Reception of Ottoman Heritage in the Balkan History and Culture, eds. K. Popek, M. Skrzeszewska, Kraków 2019, p. 112. 
analysis of source materials shows that the Muslims separated from the Ottoman Empire (the country with which they identified) identified themselves mainly based on their citizenship - the adoption of Serbian citizenship was often tantamount to converting to Orthodoxy and accept the Serbian identity.

This article aims to present the main questions linked to the Muslim exodus from Serbia in 1804-1862. The 1804 is the obvious turning point in the history of the Serbs, the people who lived in the Serbian lands as well. The caesura of 1862 is linked to the Čuruk Češma incident and Belgrade bombarding, which ended the Muslims' presence in the Serbian towns. However, the article focuses on the situation of "Turks" living in Serbia in the first half of the $19^{\text {th }}$ century and there is no place to more detailed analysis about the events in 1862 . The examples about the situation in garrison cities at the turn of the 1850 s and 1860 s, as well as a reference to 1862 , were a necessary clamp to close the narrative about the situation of Muslims in Serbia after their fellow believers left rural areas in 1830s.

The First Serbian Uprising (1804-1813) was a time of heroic fighting leading to the rebirth of the Serbian state, but also of pogroms against Muslims and a mass exodus from the Belgrade Pashalik. Before the insurrection, 40,000-50,000 Muslims lived in the territory of the future Serbian Principality, accounting for about $10-12.5 \%$ of the population. At first, in 1804, the rebellion was not directed against the Sublime Porte's authorities, but against the sultans' enemies - the local leaders of janissaries; even some groups of the Ottoman local elite supported the movement. As long as Serbian leaders did not openly stand against the sultan, they promised to leave alone the Muslim population of the Pashalik. It changed quickly, however. There were demands to banish the sultan's officials and restrict landlords' rights. At the beginning of 1805, sipahis (holders of a fief of land) still inhabited Serbia, but they could only live in Belgrade; without access to their lands, they were forced to collect tributes from their estates through representatives. During this period, important cities, such as Belgrade and Smederevo, were still controlled by the Ottomans, and so they became asylum for Muslims escaping from the countryside. With time, the uprising was becoming more and more anti-Islamic, quickly leading to Muslim pogroms and exiles, especially after Russia declared war against the Ottomans in 1806. Karađorđe's people intended to get rid of all "Turks" from Serbian lands, ${ }^{6}$ an attitude contested by some Serbian intellectuals, not because of humanitarian reasons but because of Serbian national interests. In 1806, the leading Serbian writer of Enlightenment Dositej Obradović convinced that only janissaries and sipahis should be banished but not simple people, such as Muslim merchants, craftsmen, and farmers,

${ }^{6}$ Г. Ни колајев ић, “[Српско-турски преговори о миру 1813], Копија дела за Р. [Русију?] от 17 јулија 1818" [in:] Грађа за историју првог српског устанка, ур. Р. Петров ић, Београд 1954, p. 152; О. Срдановић-Бараћ, Српска аграрна револуиија и пољопривреда од кочине крајине до краја прве владе кнеза Милоша (1788-1839), Београд 1980, p. 56, 60-62; K. P opek, “Geneza, przebieg oraz znaczenie powstań serbskich (1804-1814)," Studenckie Zeszyty Naukowe IFS UJ 2014, t. 6, nr 2 , p. 82 . 
who had peacefully lived among the Serbs. Obradović concocted plans that these people would be assimilated after the creation of the new Serbian state. ${ }^{7}$

Serbs ignored the appeals for the respect of Muslims' rights. After the rebels had entered cities, pogroms became common, and most "Turkish" houses were burned. Such a fate befell on Muslims in Užice, Valjevo, Smederevo, Sibnica, and Kruševac (in 1813, Kruševac was returned to the Ottoman Empire). ${ }^{8}$ Until 1813, practically nothing remained of the Muslim population of the Belgrade Pashalik: they either escaped or were killed. ${ }^{9}$ Although the end of the First Uprising in 1813 created the setting for "Turkish" refugees to return, as quickly as the following year a new insurrection started once again, and many of them were forced to leave. The creation of the half-autonomous Principality of Serbia and guarantees about the Muslim population's rights led to new remigration. In 1819, there were about 10,000-15,000 Muslims in Serbia. ${ }^{10}$

Thanks to Ottoman institutions equivalent to Serbian ones, Muslims living in the Principality of Serbia enjoyed wide administrative and legal autonomy. It is difficult to say if there was Muslim autonomy in the Principality of Serbia or Serbian autonomy in the Belgrade Pashalik, and for this very reason the period of 1815-1833 is called a diarchy or half-autonomy. The head of Ottoman institutions was the Belgrade Vizier, who acted with the help of a council (divan); the judiciary towards Muslims was under the kadis' competences; in the countryside, there were alay-begs (the administrators of sipahiliks) and muselims (müsellims; a governor of nahiyah, the Serbian equivalent was a voivode). Muslims in Serbia were the sultan's subjects, and so they were not subordinate to Serbian authorities but to Ottoman representatives. Criminal cases in which at last one Muslim was involved were judged by a kadi, not a Serbian court. ${ }^{11}$ A systematic liquidation of these privileges - in the countryside in the 1830s and in the cities in 1860s - gave Muslims an important reason for emigration, although they had the right to stay in Serbia, but as Serbian citizens. Most of them did not accept the subordination to Christian authorities, however. ${ }^{12}$

${ }^{7}$ M. Madžij a mić, Od tradicije do identiteta. Geneza nacionalnog pitanja bosanskim muslimana, Zagreb 1990, pp. 156-157.

${ }^{8}$ Т.Р. Ђорђев ић, “Вароши у Србији за време прве владе кнеза Милоша Обреновића" [in:] Насељавање Србије. Насеља, порекло, становиштва, обичаји, прир. Б. Челиковић, Београд 2011, pp. 786-787; “Кнез Милош Обреновић депутацији у Цариграду, Крагујевас 14.06.1830, бр. 5" [in:] Дипломатско представништо Србије у Цариграду, т. 1: 1830-1858, прир. М. Пери шић, А. Марковић, С. Рајак, Београд 2015, p. 35.

9 W. Höpken, "Der Exodus: Muslimische Emigration aus Bulgarien im 19. und 20. Jahrundert" [in:] Osmanen und Islam in Südosteuropa, Hrsg. R. La u er, H.G. Maje r, Berlin-Boston 2014, p. 313; М. Па ларе, Балканските икономики 1800-1914 г. Еволюиия без развитие, прев. М. Кон да ков а, София 2005, p. 41.

10 J. Mc Carthy, "Muslim in Ottoman Europe: Population from 1880 to 1912," Nationalities Papers 2000 , vol. 28 , no. 1 , p. 32 .

${ }^{11}$ FO 78/1672/218-225, Mr. Longworth to Sir Bulower, Belgrade 3.07.1862; Ј. Милићевић, “Историја предаје турских градова у Србији српској влади 1867. године” [in:] Ослобођење градова у Србији од Турака 1862-1867. године, ур. В. Чуб р и ло в и ћ, Београд 1970, pp. 246-247.

12 FO 421/340/206-209, Sir H. Bulwer to Earl Russell, Constantinople 11.09.1862. 
The Principality of Serbia held the Ottoman land system in the countryside until the 1830s. Sipahiliks (as the timar was usually called in Serbia) - lands formally belonging to the sultan but later given out in a lease in perpetual use for military service - played a key role in agriculture. A sipahi leased lands to Christian peasants; he could not sell it, and formally did not have rights to inheritance. Until the $18^{\text {th }}$ century, also chiftliks - great private landed estates, whose owners were called beys - expanded in the Pashalik of Belgrade and functioned as sipahiliks, but the position of farmhands was worse. During the diarchy, Prince Miloš's administration took legal actions against beys. In 1819, most chiftliks were liquidated, based on Serbian authorities' claims that they had illegally arisen against Ottoman law. There were also steps taken against fraudulent sipahis who overcollected taxes from Serbian peasants: the collection of these levies was under stricter and stricter control of Miloš's administration. On the other hand, the authorities tolerated the unlawful practice of the new class of Serbian landowners who had connections with the Obrenovic family, which resulted in peasant rebellions, of which the greatest was the Đakova buna in $1825 .{ }^{13}$

Before the uprisings, cities in the Belgrade Pashalik were dominated by the Muslims, who accounted for $65 \%$ of the urban population. This share drastically decreased after 1804, which was accompanied by a deurbanization process, with the cities losing their roles of economic and social centers. In Belgrade, the process of Muslims' disappearance was delayed, due to the pacification of the city in 1813 and the mass exodus of Serbian citizens to Austria. After 1815, however, most of them returned and simultaneously some Muslims left the city - but not many, because of Belgrade's status as the administrative center and the Vizier's headquarters (until 1841, Serbian central institutions were located in Kragujevac). ${ }^{14}$

The Adrianople Treaty, which ended the Russo-Turkish War of 1827-1829, played a key role not only in the Greek War of Independence, but also in the events in Serbia. Having promised to recognize the Principality as a vassal state (a similar status to that Moldavia and Wallachia had), the Ottoman Empire expanded the Principality's boundaries to the six nahiyahs that were under Serbian rule during the First Uprising (Krajina, Crna Reka, Paraćin, Kruševac, Stari Vlah, and Jadar with Rađevina), a decision announced in the so-called first hattisharif of 30 (18 o.s.) September 1829. Motivated by the information that Serbia would become a separate state, Muslims started to emigrate not only from the formally annexed lands, but also from the other parts of the Principality. The Sublime Porte protested and accused Serbian authorities for forced departures, and these departures became the excuse to delay the imple-

${ }_{13}$ Турии са стране кнезу Милошу. Фонд Књажеске канцеларије. Документи на турском језику Архива Србије, прев. и прип. М. Марин ков ић, Београд 2009, pp. 54-56, 60; О. Срданов и ћ-Бараћ, Српска аграрна револуиија, pp. 13-20, 99-100; N. Kršljanin, "The Land Reform of the 1830s in Serbia: The Impact of the Shattering of the Ottoman Property System," Вестник СПбГУ. Право 2017, т. 8, вып. 1, pp. 27-31.

14 Т. Р. Ђорђев ић, “Вароши у Србији,” рр. 790-791. 
mentation of the first hattisharif. ${ }^{15}$ Such a promise was nothing new to Serbians: The sultan had twice promised to recognize the vassal status of Serbia and give back the six nahiyahs - in the Bucharest Treaty of 1812 and the Akkerman Convention of 1826 - but after all, he had not kept the word. However, under the Russian pressure, the Ottomans proceeded to talk with the authorities in Kragujevac. The Sublime Porte accepted the resettlement of Muslims from the territories that had been under Serbian rule until 1815, but they protested against emigration from the six nahiyahs. ${ }^{16}$

These negotiations led to the second hattisharif of 11 December (29 November o.s.) 1830, which regulated the Muslim question in Serbia in more expanded ways. The Serbian government got control over the timar system, with the right to fully dispose of sipahiliks (the collection of lease fees, the termination of a lease agreement, and the conclusion of new ones). The state became the owner of these lands. Only the Muslims who lived in the garrison cities (Belgrad, Šabac, Sokol, Užice, Kladovo, and Smederevo) had the right to keep their Ottoman citizenship; others had to choose between (1) becoming a Serbian subject and (2) selling the property and leaving the country within a year. A special commission was issued to evaluate these properties, based on which those who would not sell their estates would be compensated. ${ }^{17}$

Once again, however, the Sublime Porte did not fulfill the promises. They assumed that Russia would lose interest in the question and the status of Serbia would remain unchanged. Ottoman authorities refused to transfer the six nahiyahs and tried to convince the Muslims from the Principality not to leave their homes. Despite this, many of them started to look for buyers for their estates, a first step towards migration from Serbia. Probably nothing would change again and the second hattisharif would not come into effect, but the Ottoman Empire found itself in a serious crisis. In 1831-1833, during the First Syrian War, the Ottomans suffered a devastating defeat, and only the Russian intervention saved Constantinople from the Egyptian troops of Muhammad Ali. The Ottoman Empire became more or less a Russian protectorate, which was confirmed by the Treaty of Hünkâr İskelesi of 1833 . We should not forget about the 1831-1833 rebellion of ayans in Bosna - the so-called Great Bosnian Uprising - which was a big threat to the sultan's rule in the Western Balkans. Taking upper hand of the sultan's difficult situation, at the end of 1832, Prince Miloš Obrenović I occupied the Kruševac Nahiyah, under the pretext of protecting Serbians living there. After that, he took control over the other five nahiyahs. Facing fait accompli and Russian pressure, the Ottoman Empire returned to negotiations. ${ }^{18}$

15 “Кнез Милош Обреновић депутацији у Цариграду, Крагујевас 26.03.1830, бр. 1” [in:] Дипломатско представништо Србије у Цариграду, т. 1, pр. 19-22; М. То до р о в и ћ, “Хатишерифи из 1830. и 1833. године и земљишна својина у Србији," Зборник радова Правног факултета у Нишу 2012, бр. 62, pp. 472-473.

16 “Кнез Милош Обреновић депутацији у Цариграду, Крагујевас 26.03.1830, бр. 2” [in:] Дипломатско представништо Србије у Цариграду, т. 1, рр. 22-24.

${ }_{17}$ Р. Љушић, Кнежевина Србија, pp. 6-12; Б. Попо в ић, Дипломатска историја Србије, Београд 2010, pp. 162-164; N. Kršlj a n i n, “The Land Reform,” p. 32; М. Тодор о в и, “Хатишерифи из 1830. и 1833.," pp. 473-474.

${ }^{18}$ N. Kršljanin, “The Land Reform,” pp. 32-33. 
The Sublime Porte was ready to fulfill the agreement of 1830 , but only under the condition that the period for the Muslims who wanted to leave Serbia would be extended to six years. The Ottomans also pressured that Muslims could stay not only in the garrison cities, but also in their suburbs. Miloš Obrenović I agreed to the first condition but not to the second one. ${ }^{19}$ The third hattisharif, officially announced on 16 (4 o.s.) December 1833, offered a compromise solution. The Muslims of Serbia had five years to choose between (1) becoming Serbian citizens and (2) selling their properties in the countryside and moved to the territory of the sultan's jurisdiction (Ottoman Empire or one of the garrison towns). The government in Kragujevac was obligated to compensate for abandoned estates that would not be sold before 1838. Muslims were expelled from the suburbs of all cities, except for Belgrade. The "Turks" living in cities were still treated like the sultan's subjects who were under Ottoman law, but they had to obey to the Serbian police. Citizens were not allowed to carry weapons in the towns; only Ottoman soldiers of the garrisons, Serbian officials, and the police could be armed. ${ }^{20}$

Contrary to the ineffectual documents issued between 1812 and 1830 that regulated the status of Serbia and the Muslims who lived there, the third hattisharif basically came into effect. Next to the border changes, its most important result was the eviction of sipahis and the liquidation of the timar system. Sipahiliks became the property of the Serbian state, which could terminate the contract and give the lands to the peasants working on them. ${ }^{21}$ Not only farmers benefited from the third hattisharif, but also Serbian immigrants did: people moved from the other parts of the Principality to the new territories, including settlers who arrived from the Ottoman Empire (Bosnia, Kosovo, and Niš Sanjak) and Montenegro. ${ }^{22}$

Just after the third hattisharif was introduced many Muslims left their homes in a hurry, even though they had time to 1838 . At the beginning of 1834, Serbian officials described the chaos linked to the precipitate selling out of the properties by Muslims. ${ }^{23}$ Serbian-Turkish negotiations related to eviction brought about many conflicts between Serbians and "Turks." In February 1832, Užice faced riots: the Muslims gained an advantage and banished Serbian families from the city. ${ }^{24}$ When the interventions of the Serbian government failed, in March 1835, the local Vizier got

${ }_{19}$ FO 421/340/100-102, Mr. Lumley to Earl Russell, St. Petersburgh 24.07.1862.

20 “Превод фермана, адресираног Књазу Србском Милошу, Цариград 13.11.1833, бр. 29” [in:] Дипломатско представниито Србије у Цариграду, т. 1, pp. 100-103.

${ }^{21}$ M. Luković, "Development of the Modern Serbian State and Abolishment of Ottoman Agrarian Relations in the $19^{\text {th }}$ Century," Ćeský lid 2011, vol. 98, no. 3, p. 297.

22 Архивска граћа за несеља у Србији у време прве владе кнеза Милоша (1815-1839), ур. Т.Р. Ђорђ в в ћ, Београд-Земун 1926, pp. 221, 224-225, 236, 258, 467-468.

23 “Петар Ђорђевић кнезу Милошу, Ћуприје 7.02.1834" [in:] Архивска граћа за несеља у Сpбијu, pp. 205-206; “Матеј Ненадовић кнезу Милошу, Рача 9.03.1831” [in:] Архивска граћа за несеља у Србији, рр. 329-330.

24 “Јован Обреновић кнезу Милошу, Чачак 27.03.1832” [in:] Архивска граћа за несеља у Cpбијu, p. 464; “Суд Народни Србски кнезу Милошу, Чачак 17.10.1832” [in:] Архивска граћа за несељь у Србији, pp. 464-465. 
involved and succeeded to convince the Muslims to let in the Serbs to their homes. ${ }^{25}$ But then came the revenge - before the 1830s, in the Užice Nahiyah, many estates and lands belonged to "Turks," for which they got the minimum compensation after leaving due to the third hattisharif. Many of the former owners protested against Serbian authorities; the resulting trials lasted for years, with some still not having ended during the Ustavobranitelji Regime and the second rule of Miloš Obrenović I. ${ }^{26}$ A more dangerous conflict took place in the Sokol region, where in 1832, 2,594 Mus$\lim$ families lived in 28 villages. They refused to leave their homes and announced that they did not accept any hattisharif that would obligate them to do so. ${ }^{27}$ Treating this as open insubordination of Muslims, Miloš Obrenović sent in June 1832 troops to the Sokol Nahiyah. He ordered them to expel Muslims without direct violence against people and arsons, but the military were allowed to intimidate the victims by destroying their properties and crops. The action took place also in regions located along the Drina River near the Bosnian border, in the Mali Zvornik area. In July, the Prince's brother Jovan Obrenović reported the action's success and the escape of most Muslims from this territory. ${ }^{28}$ Cuprija, Kruševac, and Aleksinac faced similar conflicts, but not so serious. ${ }^{29}$ Many of Muslims living in the garrison cities, who could stay, decided to migrate anyway. For example, in 1836, information emerged about the mass exodus of "Turks" from Šabac. ${ }^{30}$

The migrants' fate was far from easy. In cases of litigation with Serbian authorities or citizens, they were a lost cause: the courts directly asked the government's representatives what sentence they should give. ${ }^{31}$ Muslim property rights were undermined by accusations that property deeds (tapi) had been forged or estates had been gained by corruption. ${ }^{32}$ In many situations, compensation was either reduced or not paid for years. ${ }^{33}$ Miloš Obrenović I did not share this attitude, however. He instructed local officials that the amends be equitable and Muslim emigrants be treated worthi-

25 “Јован Обреновић кнезу Милошу, Београд 16.03.1835” [in:] Архивска граћа за несеља у Србији, pp. 466-467.

${ }^{26}$ С. Иг н и, “Муслиманска имања у Ужицу” [in:] Ослобођење градова у Србији, p. 377.

27 “Списак свију турских села у Соколској Нахији и у њима наодећих се кућа и у овима живећих турких племена, Азбуковац 14.11.1832” [in:] Архивска граћа за несеља у Србији, p. 331.

${ }^{28}$ Архивска граћа за несеља у Србији, p. 334.

${ }^{29}$ Р. Љушић, Кнежевина Србија, р. 319.

30 “Лазар Тодоровић кнезу Милошу, Шабац 10.02.1836” [in:] Архивска граћа за несеља y Србији, pp. 348-349; “Кнез Милош Лазару Тодоровићу, 14.04.1836” [in:] Архивска граћа за несеља у Србији, рр. 349-350.

31 “Суд нахије Крушевачке кнезу Милошу, Крушевац 26.06.1833” [in:] Архивска граћа за несеља у Србији, рр. 184-185.

32 “Суд Окружија Раaаћинског кнезу Милошу, Ражањ 18.08.1834” [in:] Архивска граћа за несеља у Србији, pp. 220-221; “Средоје Арсенијевић кнезу Милошу, Солотуш 28.07.1824” [in:] Архивска граћа за несеља у Србији, р. 459.

${ }_{33}$ FO 78/1749/67-72, Mr. Longworth to Sir Bulwer, Belgrade 26.01.1863; FO 78/1868/110-118, Blunt to Chargé d'affaires in Contantinople, Belgrade 9.02.1865; “Кнез Милош Обреновић депутацији у Цариграду, Крагујевас 9.03.1832, бр. 21” [in:] Дипломатско представништо Србије у Цариграду, т. 1, pp. 85-87. 
1y. ${ }^{34}$ In February 1834, he wrote to Milosav Zdravković, "The Turks have to be satisfied with the transaction, so that they don't look for anything later ... Let the Arnauts see how much mercy we give them, so that they won't regret." ${ }^{35}$

In the 1830 s, the Muslim community's social structure transformed greatly in Serbia - they were not rich officials and landlords anymore, but only poor soldiers and craftsmen. Social differences between a growing Serbian bourgeoisie (especially in Belgrade, Smederevo, and Šabac) and increasingly poor Muslims were becoming more and more apparent. ${ }^{36}$ Before the First Uprising, 40,000-50,000 Muslims lived in the Belgrade Pashalik and 7,500 in the six nahiyahs annexed in 1833. In 1834, their number decreased to about 24,000; most of them concentrated in garrison cities, where the majority of the "Turks" who did not want to leave the Principality moved. Muslims remained a majority only in Belgrade and Užice. ${ }^{37}$ Also that changed quicly - in 1845, in Belgrade, there were 1,763 Serbian households, 724 Muslim, and 129 Jewish. ${ }^{38}$ The biggest groups of the evicted Muslims went to garrison cities (mainly Belgrade and Užice) or to the south of the Principality - to Kosovo, which included the Nisch region later annexed by Serbia, in 1878. The Ottoman authorities direct newcomers to areas of strategic importance and wanted to build a "living buffer" to stop future expansion of the Serbian state..$^{39}$

The eviction of "Turks" from the countryside did not close the Muslim question in Serbia: many issues that the three hattisharifs regulated remained unchanged anyway. Despite the agreements, after 1838 some Muslim peasants with the Ottoman citizenship still lived outside the garrison cities, for example, in the areas of Šabac, Smederevo, and Sokol. ${ }^{40}$ What is more, in practice, Muslims living in cities (where they were called erlijas ${ }^{41}$ ) still were not subordinated under the Serbian police and did not pay local taxes. Civilians did not respect the ban on carrying weapons. The Muslim autonomy remained in power; it was just territorially limited to the garrison cities. Until the beginning of the 1860 s, the Islamic urban communities came into

${ }^{34}$ FO 224/2/14, British Consulate General in Serbia to Lord Ponsonby, Belgrade 13.10.1838.

35 “Кнез Милош Милосаву Здравковићу, Крагујевац 18.02.1834” [in:] Архивска граћа за несеља у Србији, pp. 207-208.

${ }^{36}$ FO 224/1/111-113, British Consulate General in Serbia to Lord Palmerston, Belgrade 10.02.1838; J. Милићевић, “Историја предаје турских градова," pp. 244-245.

37 “Димитрије Давидовић кнезу Милошу, Цариград 20.08.1830, бр. 8” [in:] Дипломатско представништо Србије у Цариграду, т. 1, pp. 43-44; Н. Тодо ро в, Балканският град XV-XIX век. Социално-икономическо и демографско развитие, София 1972, р. 316; Р. Љушић, Кнежевина Србија, p. 315; M.S. Protić, "Migration Resulting from Peasant Upheavals in Serbia during the XIXth century" [in:] Migrations in Balkan History, ed. N. Ta s i ć, Belgrade 1989, p. 92.

38 "Списак колико се у вароши овој, кућа србски, турски и јеврејски состоји, Београд 18.06.1845” [in:] Живети у Београду. Документа Управе града Београда, књ. 2: 1842-1850, ур. Б. Прп а, Београд 2004, p. s. 228.

${ }^{39}$ FO 260/11/30-31, Mr. Gould to the Marquis of Salisbury, Belgrade 29.08.1878.

40 Дипломатско представништво Србије у Цариграду, т. 2: 1859-1868, прир. М. Пер ишић, А. Марковић, С. Рајак, Београд 2015, pp. 27-31.

${ }^{41}$ Initially, they were local Janissaries (tur. yerli), recruited from the local Muslims in a province, unlike the so-called "Sublime Porte Janissaries" recruited through the devshirme system. However, in the $19^{\text {th }}$ century in Serbia, that term was used to Muslim townsmen. 
many conflicts with the Serbian population. Although not many "Turks" lived there, those who lived in compact groups in separate mahalas (town districts), had a wide administrative autonomy, and were protected by the Ottoman garrison soldiers. Almost everyone carried a weapon in cities, so quarrels often went further than fights, even resulting in gunshot wounds and deaths. ${ }^{42}$

This whole situation caused many ethnic incidents. For example, in May 1859, Husem Memedović got into a fight with two Serbs in a coffee house in Šabac; one of the Christians died because of the injuries. Even though the erlija had been accused of similar crimes before, he had never been convicted, because the local kadi had acquitted him every time, so he felt unpunished. This case ended the same way, with him not being punished for murder. ${ }^{43}$ In May 1861, there was an assault on a Serbian family in the village of Posten (the Podrinje District) by fifty "Turks" led by Asan Rešić, Mehmed Tičić, and Omer Zukapović. It led to the death of the farmer's wife. Also these perpetrators were released by the local kadi (even though the Ottoman authorities had no power in the countryside). ${ }^{44}$ In many other cases, the Serbian police arrested red-handed Muslims who were taken over by the Ottoman soldiers and let free. ${ }^{45}$ Serbian authorities openly described the anarchy and accused Muslim autonomic institutions of protecting criminals. ${ }^{46}$ This problem was alive until 1862, when the Sublime Porte permitted banishing erlijas from Serbian cities after bombarding Belgrade by the Ottoman garrison of the Kalemegdan fortress. ${ }^{47}$

$$
* * *
$$

In the $19^{\text {th }}$ century, the Serbian policy towards Muslims was based on the rule "fewer Turks, freer Serbia." 48 These exact words were said by Prince Milan Obrenović IV, but the idea was earlier picked up by the leaders of the First Serbian Uprising, who aimed to banish all "Turks" from the Belgrade Pashalik, no matter if Turkish-, Albanian- or Slavic-speaking. After the emergence of their state, Serbians strove for the goal with the help of agreements with the Sublime Porte, on which Serbia de-

${ }^{42}$ Н. Христић, Пре педесет година. Чурук-чешма, бомбардовање Београда 3-5 јула 1862, Београд 1912, pp. 17-18, 23-24; Живети у Београду. Документа Управе града Београда, књ. 1: 1837-1841, ур. Б. Пр па, Београд 2003, pp. 168-174; Живети у Београду, књ. 2, pp. 218-239.

43 АС МУД-П 1863 ф. ХХІІ р. 65 бр. 2967, Началник Округа Шабацког Министарству унутрашњих дела, Шабац 30.07.1859; АС МУД-П 1863 ф. ХХІІ р. 65 бр. 3948, Началник Округа Београдског Министарству унутрашњих дела, Београд 11.05.1859.

44 АС МУД-П 1862 ф. XVI р. 16 бр. 3321, Началник Округа Подринског Министарству унутрашњих дела, Лозница 9.05.1861.

${ }^{45}$ Н. Христи П, Пре педесет година, рр. 4-9.

46 АС МУД-П 1862 ф. II р. 150 бр. 1096, Началник Округа Црноречког Министарству унутрашњих дела, Зајчар 9.02.1862; АС МУД-П 1862 ф. XVI р. 40 бр. 3888, Управител Вароши Београда Министарству унутрашњих дела, Београд 29.05.1862.

47 See: Ž. Đo đev ić, Čukur-česma 1862. Studija o odlasku Turaka iz Srbije, Beograd 1983; 3. J a н ко в и ћ, Пут у Цариград. Кнез Михаило, предаја градова и одлазак Турака из Србије, Београд 2006.

48 S. Bandžović, Deosmanizacija Balkana i Bošnjaci: ratovi i muhadžirska pribježišta (1876.1923.), Sarajevo 2013, pp. 137-138. 
pended as its half-autonomic province first and its vassal later. It was not an easy task. Ottoman authorities repeatedly permitted the eviction of the Muslim population from the Principality, but due to a weak Serbian position, they failed to implement the arrangements later. In 1833, the situation changed. The Sublime Porte let Serbian authorities banish Muslims from their territory, including the six nahiyahs then incorporated into Serbia, but except for the garrison cities. Thanks to its growing position in the Balkans, Serbia could take more and more resolute actions against Muslims.

In the first half of the $19^{\text {th }}$ century, many Serbian intellectuals tried to convince the state's authorities that Muslims should not be banished but assimilated. Vuk Karadžić considered everybody a Serb, no matter if Albanized, Turkified, or Islamized. According to him, the goal of the Serbian state was to remind people about their origin. A similar position was represented by Ilija Garašanin, the prime minister of Serbia (1852-1853, 1861-1867) and author of one of the most important documents in the $19^{\text {th }}$-century Serbian history: Načertanije. He assumed that the Southern Slavs should be unified regardless of religion..$^{49}$ In some aspects, these ideas were linked with some contempt toward Muslims. A Serbian representative in Constantinople and one of the main negotiators of 1829, 1830, and 1833 hattisharifs, Dimitrije Davidović stressed that the Muslims living in Serbia "did not know who they were, they were simple and foolish people who should be first baptized and learn to read and write." ${ }^{50} \mathrm{In}$ practice, Muslims, who did not fled from the Serbian state and accepted the Serbian citizenship, with time converted to Orthodoxy and gradually assimilated into Serbian culture.

Serbs removed "Turks" from their state during its first fifty years, with a crucial moment in the process being the eviction that started during the First Uprising and ended in 1862. Several factors contributed to this process. First of all, only long after the Serbian state had emerged was any system of minority protection established in the region, something introduced in 1878 by the Berlin Congress. Had Serbs started to build their state after the congress - so in the circumstances of the "Berlin Order" - the situation would have been much different. These differences are seen when we compare the eviction of "Turks" from Serbia in the 1830s and 1860s on the one hand with the Muslim exodus from the Nisch Sandjak after 1878. It would likely have resembled the Bulgarian experience in similar matters: right after the creation of the Bulgarian state, Muslims constituted $26 \%$ of the population, a number that has dropped to the $8 \%$ Bulgaria has today. Also the Greek state, created in quite similar circumstances as the Serbian one, showed the same tendencies in decreasing numbers of Muslims and in the policy towards them after the War of Independence on the one hand, and after the annexation of Tesally in 1881, in the circumstances of the "Berlin Order", on the other. We should also remember that in the Ottoman period, fewer Muslims lived in the Belgrade Pashalik than in other parts of the Balkans. Muslims had already massively migrated from Serbian lands, because of the Austrian-Turkish

${ }^{49}$ M. Madžija mić, Od tradicije do identiteta, pp. 157-158.

50 “Димитрије Давидовић кнезу Милошу, Цариград 20.09.1830, бр. 12” [in:] Дипломатско представништо Србије у Цариграду, т. 1, р. 64. 
Wars in the $18^{\text {th }}$ century. The Serbian case shows that it was much easier to banish Muslims from areas where they did not constitute a compact community, yet another similarity to Greece.

The most rapid migration process took place during the unrest linked to the uprisings and the passage of territory from one jurisdiction to another, after which the Serbs did not openly banish Muslims but preferred to non-invasively assimilate them as they did other minorities: Vlachs, Jews, Greeks, and Roma. ${ }^{51}$ This process helped unify the Serbian state. The most objective measure of policy evaluation is its impact, and from this perspective, we can see the Serbian national policy in the nineteenth century as directed against Muslims, because it led to their disappearance from the Serbian state.

\section{BIBLIOGRAPHY}

\section{Archival Sources}

Archive of Serbia, Belgrade (Архив Србије, АС): МУД-П (Министарство унутрашњих дела - Полицајно одељење).

Foreign Office Archives, Public Record Office, London (FO): 78 (Political and Other Departments: General Correspondence before 1906, Ottoman Empire), 421 (Confidential Print South-East Europe, Bulgaria: Correspondence), 224 (Consulate, Serbia, Ottoman Empire: Letter Books), 260 (Consulate and Legation, Serbia: General Correspondence).

\section{Printed Sources}

Архивска граћа за несеља у Србији у време прве владе кнеза Милоша (1815-1839), ур. Т. Р. Ђорђев ић, Београд-Земун 1926.

Грађа за историју првог српског устанка, ур. Р. Пе тр о в ић, Београд 1954.

Дипломатско представништо Србије у Цариграду, т. 1: 1830-1858, прир. М. Периши ћ, А. Марковић, С. Р ај ак, Београд 2015.

Дипломатско представништо Србије у Цариграду, т. 2: 1859-1868, прир. М. Периши ћ, А. Марковић, С. Р ај ак, Београд 2015.

Живети у Београду. Документа Управе града Београда, књ. 1: 1837-1841, ур. Б. Пр па, Београд 2003.

Живети у Београду. Документа Управе града Београда, књ. 2: 1842-1850, ур. Б. Пр па, Београд 2004.

${ }^{51}$ V. Pavlović, "La naissance du concept des minorités dansles Balkans au XIX e siècle le cas de la Serbie" [in:] Minorities in the Balkans. State Policy and Interethnic Relations, ed. D. B a taković, Belgrade 2011, pp. 33-48. 
Турии са стране кнезу Милошу. Фонд Кьажеске канцеларије. Документи на турском језику Архива Србије, прев. и прип. М. Мари н ко в ић, Београд 2009.

Христић Н., Пре педесет година. Чурук-чешма, бомбардовање Београда 3-5 јула 1862, Београд 1912.

\section{Literature}

Bandžović S., Deosmanizacija Balkana i Bošnjaci: ratovi i muhadžirska pribježišta (1876.-1923.), Sarajevo 2013.

Đo đević Ž., Čukur-česma 1862. Studija o odlasku Turaka iz Srbije, Beograd 1983.

Höpken W., "Der Exodus: Muslimische Emigration aus Bulgarien im 19. und 20. Jahrundert" [in:] Osmanen und Islam in Südosteuropa, Hrsg. R. La u er, H. G. Maj er, BerlinBoston 2014, pp. 303-433.

Immig N., "The 'New' Muslim Minorities in Greece: Between Emigration and Political Participation, 1881-1886," Journal of Muslim Minority Affairs 2009, vol. 29, no. 4, pp. 511-522.

Katsikas S., "Millet Legacies in a National Environment: Political Elites and Muslim Communities in Greece (1830s-1923)" [in:] State-nationalisms in the Ottoman Empire, Greece and Turkey: Orthodox and Muslims, 1830-1945, eds. B. Fortna, S. Kats ik as, D. K a m o uzis, P. K o n ort a s, Abingdon-New York 2013, pp. 47-84.

Kršljanin N., "The Land Reform of the 1830s in Serbia: The Impact of the Shattering of the Ottoman Property System,” Вестник СПбГУ. Право 2017, т. 8, вып. 1, pp. 26-41.

Luković M., "Development of the Modern Serbian State and Abolishment of Ottoman Agrarian Relations in the $19^{\text {th }}$ Century," Český lid 2011, vol. 98, no. 3, pp. 281-305.

Madžij a m ić M., Od tradicije do identiteta. Geneza nacionalnog pitanja bosanskim muslimana, Zagreb 1990.

M c Carthy J., Death and Exile: The Ethnic Cleansing of the Ottoman Muslims 1821-1922, Princeton 1996.

Mc Carthy J., "Muslim in Ottoman Europe: Population from 1880 to 1912," Nationalities Papers 2000, vol. 28, no. 1, pp. 29-43.

Pavlović V., "La naissance du concept des minorités dans les Balkans au XIXe siècle le cas de la Serbie" [in:] Minorities in the Balkans. State policy and interethnic relations, ed. D. B ataković, Belgrade 2011, pp. 33-48.

P opek K., "Geneza, przebieg oraz znaczenie powstań serbskich (1804-1814)," Studenckie Zeszyty Naukowe IFS UJ 2014, t. 6, nr 2, pp. 77-90.

Popek K., "Muslim Emigration from the Balkan Peninsula in the $19^{\text {th }}$ Century: A Historical Outline," Zeszyty Naukowe UJ. Prace Historyczne 2019, vol. 146, no. 3: Migrations, Migrants and Refugees in $19^{\text {th }}-21^{\text {st }}$ Centuries in the Interdisciplinary Approach. Selected Topics, eds. P. Sęk ow ski, O. Forcade, R. Hudemann, pp. 517-533.

Popovic A., L'Islam balkanique, Les Musulmans du Sud-Est européen dans la période post-ottomane, Wiesbaden 1986.

Protić M.S., "Migration Resulting from Peasant Upheavals in Serbia during the XIXth century” [in:] Migrations in Balkan History, ed. N. Ta s i ć, Belgrade 1989, pp. 91-96.

Skrzeszewska M., "Poturica gori od Turčina or...? The Influence of Islam on 'Our Muslims' in Serbian Nationalistic Discourse (Review from the Second Half of the $19^{\text {th }}$ Century to the 1920s)" [in:] Turkish Yoke or Pax Ottomana. The Reception of Ottoman Heritage in the Balkan History and Culture, eds. K. Popek, M. Skrzes zew s ka, Kraków 2019, pp. 111-130. 
Turan Ö., The Turkish Minority in Bulgaria (1878-1908), Ankara 1998.

Ђорђев ић Т.Р., "Вароши у Србији за време прве владе кнеза Милоша Обреновића” [in:] Насељавање Србије. Насеља, порекло, становништва, обичаји, прир. Б. Чел и ко в и , Београд 2011, pp. 783-806.

Игнић С., “Муслиманска имања у Ужицу” [in:] Ослобођење градова у Србији од Турака 1862-1867. године, ур. В. Чубр и ло в ић, Београд 1970, pp. 377-386.

Јанковић 3., Пут у Цариград. Кнез Михаило, предаја градова и одлазак Турака из Србије, Београд, 2006.

Љ уши и Р., Кнежевина Србија (1830-1839), Београд 1986.

Милићевић Ј., "Историја предаје турских градова у Србији српској влади 1867. године" [in:] Ослобођење градова у Србији од Турака 1862-1867. године, ур. В. Чу бр ил о в и , Београд 1970, pp. 243-249.

Назърска Ж., Българската държава и нейните малиинства 1878-1885 г., София 1999.

Насељавање Србије. Насеља, порекло, становништва, обичаји, прир. Б. Че л и ко в и ћ, Београд 2011.

Паларе М., Балканските икономики 1800-1914 г. Еволющчя без развитие, прев. М. Кон да ко в а, София 2005.

По по в ић Б., Дипломатска историја Србије, Београд 2010.

С рдан о в ић-Бар аћ О., Српска аграрна револуичја и пољопривреда од кочине крајине до краја прве владе кнеза Милоша (1788-1839.), Београд 1980.

Тодо ро в Н., Балканският град XV-XIX век. Сочиилно-икономическо и демографско развитие, София 1972.

Тод о р о в и Ћ М., “Хатишерифи из 1830. и 1833. године и земљишна својина у Србији,” Зборник радова Правног факултета у Нишу 2012, бр. 62, pp. 463-478. 